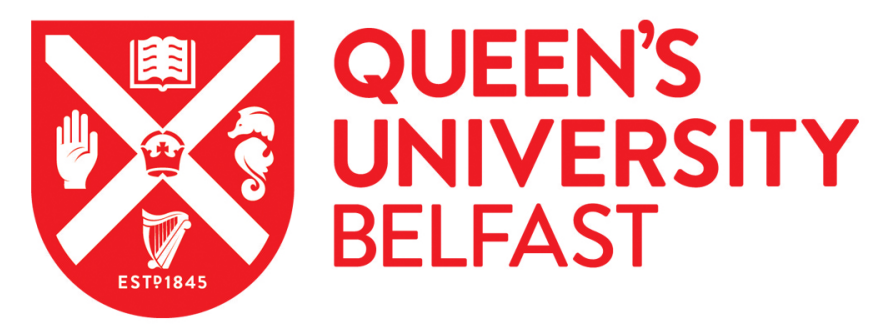

\title{
Anthropometric History: Revisiting what's in it for Ireland
}

McLaughlin, E., Colvin, C. L., \& Blum, M. (2021). Anthropometric History: Revisiting what's in it for Ireland. Irish Economic and Social History, 48(1), 3-26. https://doi.org/10.1177/0332489320913179

\author{
Published in: \\ Irish Economic and Social History
}

Document Version:

Peer reviewed version

Queen's University Belfast - Research Portal:

Link to publication record in Queen's University Belfast Research Portal

Publisher rights

Copyright 2020 The Authors. This work is made available online in accordance with the publisher's policies. Please refer to any applicable terms of use of the publisher.

\section{General rights}

Copyright for the publications made accessible via the Queen's University Belfast Research Portal is retained by the author(s) and / or other copyright owners and it is a condition of accessing these publications that users recognise and abide by the legal requirements associated with these rights.

Take down policy

The Research Portal is Queen's institutional repository that provides access to Queen's research output. Every effort has been made to ensure that content in the Research Portal does not infringe any person's rights, or applicable UK laws. If you discover content in the Research Portal that you believe breaches copyright or violates any law, please contact openaccess@qub.ac.uk. 


\title{
Anthropometric History: Revisiting what's in it for Ireland
}

\author{
Eoin McLaughlin
}

University College Cork

\section{Christopher L. Colvin}

Queen's University Belfast

\section{Matthias Blum}

\author{
German Medical Association
}

\begin{abstract}
This research note updates Cormac Ó Gráda's (1996) critical review of the literature on the connection between the stature of the Irish, on the one hand, and their health and living standards, on the other. We find most of the anthropometric datasets used in this literature pertain to Irish emigrants rather than those who stayed behind. We therefore argue prison registers are a more appropriate source of anthropometric information. But results derived from these registers need to be handled with caution as prisoners are a selected population. We uncover the various observable selection biases inherent in prison data, and track how they change across the second half of the nineteenth century. We find changes in selection into crime across time are more likely to have been due to institutional rather than economic factors.
\end{abstract}

\section{Keywords}

anthropometrics, prison registers, sample selection bias, post-Famine Ireland

\section{Introduction}

General registers of prisoners were used to identify and track criminals in an era before birth registration and identity documentation. Held at the National Archives of Ireland and the Public Record Office of Northern Ireland, they are a popular source of micro-level data for historical researchers because of the wealth of information contained within them. Aside from each prisoner's name, they record information on crimes committed, dates sentenced and released, places of birth and residence at time of incarceration, and details on recidivism, religion, literacy, marital status, occupation, age, height and weight. Registers are surprisingly wideranging in scope in that they include both males and females, the young and the old. It is not surprising that prison registers have become one of the main sources of historical anthropometric data - measurements and proportions of the human body - for the Irish population which remained in Ireland. ${ }^{1}$ These anthropometric data are of high quality as they were recorded by prison administrators and are standardised and consistent across time and place. ${ }^{2}$

\footnotetext{
${ }^{1}$ C. Ó Gráda, ‘Anthropometric history. What's in it for Ireland?' Histoire and Mesure, 11 (1996), 139-166.

${ }^{2}$ New inmates were required to undergo an obligatory medical examination by a prison doctor: C. Breathnach, 'Medical officers, bodies, gender and weight fluctuation in Irish convict prisons, 1877-95', Medical History, 58:1 (2014), 67-86.
} 
Previous anthropometric studies using prison registers refer to samples of prisoners in two specific prisons: Clonmel Gaol in County Tipperary, and Kilmainham Gaol in County Dublin. ${ }^{3}$ However, there are extant records available for 38 local county prisons, 96 bridewells and four convict prisons over the entire nineteenth century; ${ }^{4}$ there remains significant potential for additional anthropometric research. ${ }^{5}$ As few other individual-level sources of human measurement information remain, the data contained within these registers could become essential to answering questions about the changing health and living standards of Ireland's resident nonmigrant population. These custodial institutions' different geographic locations and different functions within Ireland's criminal justice system allows for interesting comparisons; researchers can, for example, distinguish between rural and urban populations, or between hardened criminals and their more common everyday counterparts incarcerated for short periods for petty crimes.

But while prison registers are an important source, they are not a panacea. Bodenhorn, Guinnane and Mroz argue various selection biases plague the anthropometrics literature, and single out prison registers for particular criticism. ${ }^{6}$ Some of these are observed biases, others are unobserved or even unobservable. Bodenhorn et al. have arguably put well-known published anthropometric findings into doubt, including work which argues there was a decline in living standards during the Industrial Revolution. Their selection bias "elephant in the room" is currently the subject of intense academic discussion. Zimran in particular has conducted a battery of tests on US data to uncover how sample selection bias affects the analysis of historical heights. ${ }^{7}$ Zimran's solution is to adopt a Heckman-style ${ }^{8}$ procedure to study the process by which individuals come to enter the samples used in anthropometric research. ${ }^{9}$

The following short research note discusses the role of anthropometrics in Irish economic history and evaluates prison registers as a source of anthropometric data more generally. The main purpose of our note is to investigate the various possible sample selection biases for the Irish case. We argue that identifying and describing these biases will permit future scholars to take them into account in their own anthropometric research, or in other research which makes use of similar institutional records for other social science history. In particular, a research project we are running on measuring the long-run health consequences of the Great Irish Famine requires us to ascertain and account for sample selection biases in these records. ${ }^{10}$ In short, we aim to reduce the magnitude of unobserved biases by observing as many biases as possible and showing how scholars can control for these in their research. We hope our understanding of the history of the health and human capital of the Irish people will consequently be much more robust.

\footnotetext{
${ }^{3}$ See, e.g., C. Ó Gráda, ‘The heights of Clonmel Prisoners 1845-9: Some dietary implications', Irish Economic and Social History, 18 (1991), 24-33; C. Ó Gráda, Ireland: A New Economic History 1780-1939 (Oxford, 1994).

${ }^{4}$ E. O'Sullivan and I. O'Donnell, 'Imprisonment and the crime rate in Ireland', The Economic and Social Review, 34 (2003), $33-64$.

5 An extensive database of biometric data from UK prisons has been made available as part of the Digital Panopticon project (https://www.digitalpanopticon.org/Biometrics).

${ }^{6}$ H. Bodenhorn, T. W. Guinnane and T. A. Mroz, 'Sample-selection biases and the "industrialization puzzle", Journal of Economic History, 77:1 (2017), 171-207.

${ }^{7}$ A. Zimran, 'Recognizing sample-selection bias in historical data', Mimeo, Vanderbilt University, Nashville (2019) [Forthcoming in Social Science History].

${ }^{8}$ J. J. Heckman, 'Sample selection bias as a specification error', Econometrica, 47:1 (1979), 153-161.

${ }^{9}$ See, separately, A'Hearn and Komlos's response to their critics. They argue Bodenhorn et al. in their discussion of the so-called "Antebellum Puzzle" - a pattern of declining health prior to the US Civil War in the presence of rising real income and wages - misperiodise the antebellum period and also include studies from Canada which have not been documented in the literature. In turn, Bodenhorn et al. dispute this criticism as selective use of evidence: B. A'Hearn and J. Komlos, 'Clarifications of a puzzle: The decline in nutritional status at the onset of modern economic growth in the United States', Journal of Economic History, 79:4 (2019), 1129. 1153; H. Bodenhorn, T. W. Guinnane and T. A. Mroz, 'Diagnosing sample-selection bias in historical heights: A reply to Komlos and A'Hearn', Journal of Economic History, 79:4 (2019), 1154-1175.

${ }^{10}$ M. Blum, C. L. Colvin and E. McLaughlin, 'Scarring and selection in the Great Irish Famine' Scarring and selection in the Great Irish Famine', Mimeo, Queen's University Belfast (2020).
} 
Ó Gráda's study of Clonmel prisoners' heights argues 'prisoners are representative of the population at large'. ${ }^{11} \mathrm{He}$ draws this conclusion from the fact that most prisoners were first-time offenders. However, in our view this is insufficient evidence of their representativeness. We are of the opinion that what is currently missing from his, and most other, anthropometric studies is the necessary context with which to interpret analyses of human stature. By context, we mean the circumstances which form the setting under which the data were recorded. In particular, there is insufficient understanding of the relevant economic and institutional context among the users of these institutional records. ${ }^{12}$ If we are to take the economics of crime literature seriously, then it is possible the selection into prisons can change over time according to the socioeconomic circumstances of the population from which the prisoners are drawn. ${ }^{13}$ Meanwhile, the criminology literature stresses selection issues due to changes to the institutions of the criminal justice system. ${ }^{14}$ These two sets of changes must be better understood and related to prison registers before we can draw any inferences on prisoners' human and health capital, or, indeed, the wellbeing of the wider population. Hence, the questions we need to address to fully understand our necessary context are as follows: (1) who ends up in jail and how; and (2) how does this change, if at all, over time.

We first survey existing literature on anthropometric studies of Ireland and of Irish people both at home and abroad. We then study the main source material for Irish people remaining in Ireland to assess the institutional nature of these sources (i.e., how people entered the prison system) and whether crime was responsive to economic factors (i.e., selection into crime). We show all areas of the island were overpoliced (relative to the rest of the UK), policing was efficient, custodial sentences were used for both serious and petty criminal offences, and the majority of prisoners were convicted for being drunk and disorderly. We find any changes in selection into crime across time were more likely due to institutional than economic factors, drawing attention to factors such as shifts in custodial and court practice.

\section{Review of Anthropometric Studies}

Modern growth models implicitly assume Thomas Malthus's 'positive check to population' to mean premature death. ${ }^{15}$ But Malthus himself took a more nuanced perspective: a generational lowering of living standards that manifests itself in bad health, where mortality is just an extreme case of bad health. ${ }^{16}$ While the generation directly affected by a positive check may eventually die prematurely, they also suffer health and social consequences in their own, shortened, lifetime. And one manifestation of such a check, which Malthus highlights explicitly in his work, is stunted body growth. Anthropometrics, the scientific study of the measurements and proportions of the human body, can therefore be dated to at least the work of Malthus.

\footnotetext{
${ }^{11}$ Ó Gráda, 'The heights of Clonmel prisoners 1845-9', p. 26.

12 A recent anthropometrics article which does attempt to incorporate context to discuss selection is Depauw and Oxley's study of Flanders prisoners exposed to potato famine. In particular, this study focuses on economic context by looking at changes to the skills composition of those imprisoned across their sample. However, the authors fail to follow through and discuss how these selection issues affect their results: E. Depauw and D. Oxley, 'Toddlers, teenagers, and terminal heights: The importance of puberty for male adult stature, Flanders, 1800-76', Economic History Review, 72:3 (2019), 925-952.

${ }^{13}$ See the review in: R. N. Freeman, 'The economics of crime', in O. Ashenfelter and D. Card (eds.), Handbook of Labor Economics, Vol. 3, Part C (Amsterdam, 1999), 3529-3571.

${ }^{14}$ See the review in: T. C. Pratt and F. T. Cullen, 'Assessing macro-level predictors and theories of crime: A meta analysis', Crime and Justice, 32 (2005), 373-450.

${ }^{15}$ See, for example: O. Galor, 'From stagnation to growth: Unified growth theory', in P. Aghion, P. and S. N. Durlauf, S. N. (eds.), Handbook of Economic Growth, Vol. 1, Part A (Amsterdam, 2005), 171-293; or O. Galor (2011), Unified Growth Theory (Princeton, 2011).

${ }^{16}$ T. R. Malthus, An Essay on the Principle of Population, as it Affects the Future Improvement of Society (London, 1798).
} 
Today, stature is widely used as an anthropometric indicator of the health status of a population in both the economic history and development economics literatures. ${ }^{17}$ Analysis of height data is at the core of the Cliometric Revolution, led to at least one Nobel Memorial Prize in Economics (for Robert Fogel), and even helped to spawn an academic journal (Economics and Human Biology). Heights reflect health and living standards from an outcome-oriented viewpoint. The mean stature of a population is a function of both official and unofficial income, such as subsistence farming, public goods, and illicit trading. ${ }^{18}$ Heights also have been found to be sensitive to the level of income inequality. ${ }^{19}$ The height of a generation is largely determined around the time of its birth, with health standards of mothers as well as nutritional and health standards of infants playing a crucial role. ${ }^{20}$ Evidence from modern-day Africa suggests genetic explanations for height differences are not convincing; ${ }^{21}$ differences across one society are much more likely due to ecological factors.

Malthus viewed the incidence of famine as 'the last and most dreadful mode by which nature represses a redundant population'. ${ }^{22}$ The work of this Anglican cleric and demographer has cast a long shadow over Irish economic history, with pre-Famine rural Ireland often viewed as having had unsustainable population levels, and the Great Irish Famine interpreted as a Malthusian catastrophe. ${ }^{23}$ A number of studies have used anthropometric indicators, and especially average societal height, as a way of analysing Malthusian pressures. Indeed, the anthropometrics literature on Ireland is largely concerned with answering questions around the impact of the Famine. Below we update the review of such studies presented by Ó Gráda; ${ }^{24}$ we consider our research note to be an update to his article.

Most anthropometric studies of Irish populations have collected data recorded during the period 1800 to 1850, such as Australian transportation records, East India Company registers, and Royal Marine and Army records. ${ }^{25}$ These studies do not contain much, if any, information regarding the cohorts born during the Famine itself and are therefore not immediately useful in measuring the impact of this nutritional and health shock. One notable exception is the dataset compiled by Fogel and collaborators, ${ }^{26}$ and used, among others, by A'Hearn. ${ }^{27}$ This contains the height of soldiers serving in the Union Army during the American Civil War and includes Irish-born immigrants to the US from cohorts born both before and during the Famine period.

But even where data are available on Famine-born individuals, these usually do not refer to samples derived from the population resident in Ireland, but rather to the Irish-born found elsewhere. None explicitly take account of the various selection biases that may occur, most notable due to migration. A consistent finding of

${ }^{17}$ R. W. Fogel, The Escape from Hunger and Premature Death, 1700-2100: Europe, America, and the World (Cambridge, 2004); A. Deaton, The Great Escape: Health, Wealth, and the Origins of Inequality (Princeton, 2013).

${ }^{18}$ R. H. Steckel, 'Stature and the standard of living', Journal of Economic Literature, 33:4 (1995), 1903-1940.

${ }^{19}$ A. Deaton, 'Height, health, and inequality: The distribution of adult heights in India', American Economic Review, 98:2 (2008), 468474.

${ }^{20}$ P. B. Eveleth and J. M. Tanner, Worldwide Variation in Human Growth (Cambridge, 1976); Steckel, 'Stature and the standard of living'.

${ }^{21}$ A. Deaton, 'Height, health, and development', Proceedings of the National Academy of Science, 104:33 (2007), 13232-13237.

${ }^{22}$ Malthus, An Essay on the Principle of Population, p. 44.

${ }^{23}$ For discussion of the Malthusian debate, see: K. H. Connell, The Population of Ireland, 1750-1845 (Oxford, 1950); J. Mokyr, Why Ireland Starved, 2nd Edition (London, 1985); P. P. L. McGregor, 'Demographic pressure and the Irish Famine: Malthus after Mokyr', Land Economics, 65:3 (1989), 228-238; and M. Kelly and C. Ó Gráda, 'Why Ireland starved after three decades: The Great Famine in cross-section reconsidered', Irish Economic and Social History, 42 (2015), 53-61.

${ }^{24}$ C. Ó Gráda, 'Anthropometric history'.

${ }^{25}$ S. Nicholas and R. H. Steckel, 'Tall but poor: Living standards of men and women in pre-Famine Ireland', Journal of European Economic History, 26 (1997), 105-134; J. Mokyr and C. Ó Gráda, 'Height and health in the United Kingdom 1815-1860: Evidence from the East India Company Army', Explorations in Economic History, 33:2 (1996), 141-168; R. K. Floud, K. Wachter and A. Gregory, Height, Health and History: Nutritional Status in the United Kingdom 1750-1980 (Cambridge, 1990).

${ }^{26}$ R. W. Fogel, S. E. Engerman, C. Pope and L. Wimmer, 'Union Army recruits in white regiments in the United States, 18611865' [Computer file], Ann Arbor, MI: Inter-university Consortium for Political and Social Research [distributor] (1990).

${ }^{27}$ B. A'Hearn, 'The antebellum puzzle revisited: A new look at the physical stature of Union Army recruits during the Civil War', in J. Komlos and J. Baten (eds.), The Biological Standard of Living in Comparative Perspective (Stuttgart, 1998), 250-267. 
these studies is that the pre-Famine Irish enjoyed a considerable height advantage over the peoples of Great Britain, despite their relative poverty - a result many attribute to their superior nutritional diet composed primarily of potatoes and butter milk. A key facet overlooked in these studies, however, is how the changing diet in the Famine and post-Famine periods might have influenced these observed trends. ${ }^{28}$

Findings from several studies that have used British military data suggest there is a noticeable scarring effect from the Famine, i.e., famine exposure lead to poor health into adulthood. Floud, Wachter and Gregory, who use data from volunteer army and navy recruits, find a significant decline in the average height of Irishmen born in the 1840s. ${ }^{29}$ In the subsequent decades they find heights rebound among Irish families which 'survived and stayed'. Using the same data, but different methods, Komlos finds the downturn in average heights had already began in the $1830 \mathrm{~s},{ }^{30}$ which he attributes to Malthusian pressures foreshadowing the Famine. ${ }^{31}$ However, neither Floud et al. nor Komlos dealt with the selection biases inherent in the volunteer army sample, such as changes to the supply and demand for soldiers over time and the place of origin of recruits in Ireland. ${ }^{32}$ In contrast, this point is addressed by Mokyr and Ó Gráda, who use comparable volunteer army recruits, this time from the East India Company over the period 1800 to $1860 .^{33}$

Studies using anthropometric data from the penal system find declining height trends before the Famine. Nicholas and Steckel use a sample of Irish-born men and women transported to New South Wales between 1817 and $1840 .{ }^{34}$ They find a modestly declining height trend for male cohorts born in the 1770s through to the 1820s. Riggs uses decadal samples from prisons in Glasgow over the period 1840 to 1880, which includes Irish-born migrants. ${ }^{35} \mathrm{He}$ finds trends in mean heights were declining for those born in the 1810 s to the $1830 \mathrm{~s}$, but that these rebounded for those born in the 1840s. Riggs interprets his results to indicate the nutritional status of the Irish-born in Scotland was already under pressure before the Famine.

New life was given to the debate by a series of studies exploiting data from the 1930 Harvard Anthropological Survey of Ireland. ${ }^{36}$ In a series of papers, Relethford, Crawford and Young use these data to answer whether there was an observable increase in stature in post-Famine Ireland. ${ }^{37}$ All three studies find evidence to support scarring, which they attribute to relief of Malthusian pressures. However, as Relethford notes, to fully address the potential impact of the Famine, data on heights before, during and after the Famine

\footnotetext{
${ }^{28}$ Clarkson and Crawford note potato consumption declined as tillage land dropped by 50\% between the 1860s and 1910: L. A. Clarkson and E. M. Crawford, Feast and Famine: Food and Nutrition in Ireland 1500-1920 (Oxford, 2001).

${ }^{29}$ This famine effect was noticeable when estimating long-run trends, so much so that Floud et al. decreed those born in famine years should be omitted as outliers: Floud et al., Height, Health and History, pp. 205 \& 211-212

${ }^{30} \mathrm{~J}$. Komlos, 'The secular trend in the biological standard of living in the United Kingdom, 1730-1860', Economic History Review, 46:1 (1993), 133-136.

${ }^{31}$ Komlos, 'The secular trend in the biological standard of living', is critical of the underlying methods used by Floud et al., Height, Health and History, to address the truncated height distribution resulting from minimum height requirements.

32 The sampling strategy of 5,000 observations-per-decade may influence this trend; a larger share of Irish-born were recruited in the 1860s than in the 1870s: Floud et al., Height, Health and History, p. 90. Furthermore, they fail to distinguish between urban and ruralborn in among Irish recruits; most Irish-born recruits were from urban centres: E. McLaughlin, 'The Irish Revolution and its aftermath: The economic dimension', in J. Crowley, D. Ó Drisceoil, and M. Murphy (eds.), Atlas of the Irish Revolution (Cork, 2007), $762-769$.

${ }_{33} \mathrm{~J}$. Mokyr and C. Ó Gráda, 'Poor and getting poorer? Living standards in Ireland before the Famine', Economic History Review, 41:2 (1988), 209-235; J. Mokyr and C. Ó Gráda. 'The heights of the British and Irish c. 1800-1815: Evidence from recruits to the East India Company's Army', in J. Komlos (ed.), Stature, Living Standards, and Economic Development: Essays in Anthropometric History (Chicago, 1994), 39-59; J. Mokyr and C. Ó Gráda, 'Height and health in the United Kingdom 1815-1860: Evidence from the East India Company Army', Explorations in Economic History, 33:2 (1996), 141-168.

${ }^{34}$ Nicholas and Steckel, 'Tall but poor'.

${ }^{35}$ P. Riggs, 'The standard of living in Scotland, 1800-1850', in J. Komlos (ed.) Stature, Living Standards, and Economic Development: Essays in Anthropometric History (Chicago, 1994).

${ }^{36}$ See Hooton and Dupertuis for description of these data: E. A. Hooton and W. C. Dupertuis, The Physical Anthropology of Ireland (Cambridge MA, 1955).

${ }^{37}$ J. H. Relethford, 'Re-examination of secular change in adult Irish stature', American Journal of Human Biology, 7:2 (1995), 249-253; J. H. Relethford and M. H. Crawford, 'Anthropometric variation and the population history of Ireland', American Journal of Physical Anthropology, 96:1 (1995), 25-38; K. Young, J. H. Relethford and M. H. Crawford, 'Postfamine stature and socioeconomic status in Ireland', American Journal of Human Biology, 20:6 (2008), 726-731.
} 
are needed, which the Harvard survey does not contain. ${ }^{38}$ Using a small dataset collected by Beddoe from the voluntary measurement of men and women in the $1860 \mathrm{~s},{ }^{39}$ they suggest pre-Famine height trends were not too dissimilar from post-Famine trends and tentatively concluded 'the Famine did not have a dramatic effect on adult stature'. ${ }^{40}$

Recently, Blum and McLaughlin use a rediscovered dataset from an experiment measuring the height of University of Edinburgh students in the 1830s, but find little evidence of Malthusian pressures foreshadowing the Famine. ${ }^{41}$ The study by Forbes ${ }^{42}$ from which the data originate was later cited by Kane as evidence that 'when at all well fed, there is no race more perfectly developed, as to physical conformation, than the inhabitants of Ireland' ${ }^{43}$ Kane in turn is cited by Mokyr and Ó Gráda. ${ }^{44}$ The rediscovered dataset shows Irish students enrolled in Edinburgh were incredibly tall by the standards of the day $(20$-year-olds were $179 \mathrm{~cm})$ and were not far off modern-day standards. Of course, the dataset used is rather small, ${ }^{45}$ and constitutes an already elite Irishborn class which left the island in pursuit of elite higher education.

There is currently a wider debate taking place in economic history on migrant selection. Anthropometric research has a potential to contribute to this. Connor finds evidence of negative selection of Irish migrants using US and Irish census records, ${ }^{46}$ while Spitzer and Zimran find evidence of negative selection among Italian migrants to the US. ${ }^{47}$ Meanwhile, Collins and Zimran find intergenerational convergence of famine-era Irish migrants to the US in terms of occupational status. ${ }^{48}$ Careful comparison of anthropometric datasets either side of the Atlantic can provide a greater appreciation of the migrant selection debate in the Irish context.

Our own recent work is probably the most expansive contribution to the study of Irish heights to date. ${ }^{49} \mathrm{It}$ enjoys a key advantage over other recent contributions: the data used pertain to non-migrants. The paper aims to measure the long-run health impact of the Great Irish Famine on Ireland's residual population, those who did not die or emigrate. It does so by isolating 21,000 individuals from two prison registers who were born immediately before, during or immediately after the Famine. Height was consistently recorded in these prison registers because it was used as a means of identifying prisoners. With the introduction of a uniform prison administration for the island, a standard set of rules on prisoner admission was enforced, making the data both consistent and comparable..$^{50}$ Our empirical strategy allows us to measure the degree to which the population which survived the Famine was permanently scarred in terms of their health, measured anthropometrically. But the fact that prisoners are a selected population means we first have to measure this selection, the subject of the present research note.

\footnotetext{
${ }^{38}$ J. H. Relethford, 'Re-examination of secular change in adult Irish stature'.

39 J. Beddoe, On the Stature and Bulk of Man in the British Isles (London, 1870).

${ }^{40}$ J. H. Relethford, 'Re-examination of secular change in adult Irish stature', p. 252.

${ }^{41}$ M. Blum and E. McLaughlin, 'Living standards and inequality in the Industrial Revolution: Evidence from the height of University of Edinburgh students in the 1830s', Economics and Human Biology, 35 (2019), 185-192.

${ }^{42}$ D. J. Forbes, 'On the results of experiments made on the weight, height, and strength of above 800 individuals', London and Edinburgh Philosophical Magazine and Journal of Science, 10 (1837).

${ }^{43} \mathrm{R}$. Kane, The Industrial Resources of Ireland (Dublin, 1845).

${ }_{44}^{44}$ Mokyr and Ó Gráda, 'Poor and getting poorer?', p. 227.

45 Of the 830 students, approximately 100 were Irish.

${ }^{46}$ D. Connor, 'The cream of the crop? Geography, networks and Irish migrant selection in the Age of Mass Migration', Journal of Economic History, 79:1 (2019), 139-175.

${ }^{47}$ Y. Spitzer and A. Zimran, 'Migrant self-selection: Anthropometric evidence from the mass migration of Italians to the United States, 1907-1925', Journal of Development Economics, 134 (2018), 226-247.

${ }^{48}$ W. J. Collins and A. Zimran, 'The economic assimilation of Irish famine migrants to the United States', Explorations in Economic History, 74 (2019): 101302.

${ }^{49}$ Blum et al., 'Scarring and selection in the Great Irish Famine'.

${ }^{50}$ Rule number 10 of the general prison rules of 1888 states 'the name, age, religious denomination, height, weight, features, particular marks, and general appearance of a prisoner shall, upon his admission, be noted in a nominal record of prisoners to be kept by the Governor': BPP [British Parliamentary Papers], Copy of Rules and Regulations in Force in the Prisons in Ireland (329) (1888).
} 


\section{Institutional Biases in Prison Data}

Prison registers are one of the most widely available and accessible sources of information for Irish people who remained in Ireland. However, to fully utilise these data requires understanding two separate selection issues: (1) selection from the general population into crime; and (2) selection from crime into our prisons. Bodenhorn et al., applying a Becker style approach, ${ }^{51}$ see individuals as being influenced by the net present value of the benefits and costs of committing crime. ${ }^{52}$ This benefit-cost matrix can vary temporally depending on, for example, institutional change, or business cycle fluctuations. Different individuals may select into crime at different times, depending on the prevailing benefit-cost matrix. To address this selection issue, we must understand whether this type of benefit-cost matrix is evident in our underlying population. We describe Ireland's criminal justice system, catalogue the types of crime individuals committed and were imprisoned for, and discuss whether and how this changed over the period under investigation.

Ireland's criminal justice system was highly sophisticated; Kilcommins et al. note it was 'incongruous with its level of industrialisation'. ${ }^{53}$ Figure 1 outlines our stylised schema of this system. Crimes were either reported or observed by police. How they were subsequently dealt with depended on how they were classified. Essentially, there were two types of offence, and the demarcation depended on the crime's severity: indictable offences (trial-by-jury) and summary offences (non-jury cases). Indictable offences related to more serious offences, such as murder, manslaughter, rape and grand larceny. ${ }^{54}$ Summary offences were often petty crimes, such as drunkenness, common assault, vagrancy, petty theft, and transgressions of acts of parliament such as infringements against the poor law acts, revenue laws and food adulteration. Toward the end of the century, summary offences were regarded as 'civil transgressions' or 'quasi-criminal offences' ${ }^{55}$ Nevertheless, summary offences comprised the majority of crimes prosecuted in Ireland over the entire nineteenth century. ${ }^{56}$

The police were the central point of any criminal investigation and they acted as prosecutors. County constabularies were established in 1822. Paramilitary forces modelled on the French gendarmerie, these were centralised into an Irish constabulary in 1836. Dublin City maintained its own police force, the Dublin Metropolitan Police. Ireland was heavily policed, with three times as many police per capita as England and Wales. ${ }^{57}$ This disparity of policing levels persisted over time. ${ }^{58}$ Constabulary returns from census occupations and other sources suggest rural areas of the island were similarly highly policed. ${ }^{59}$ The high police manifestation suggests a strong law enforcement presence throughout the period of our study.

\footnotetext{
${ }^{51}$ G. S. Becker, 'Crime and punishment: An economic approach', Journal of Political Economy, 76:2 (1968), 169-217.

${ }^{52}$ Bodenhorn et al., 'Sample-selection biases and the "industrialization puzzle"'.

${ }^{53}$ S. Kilcommins, I. O'Donnell, E. O’Sullivan and B. Vaughan, Crime, Punishment and the Search for Order in Ireland (Dublin, 2004).

${ }^{54}$ Although some indictable offences were dealt with summarily, these constitute a very small share.

55 BPP, Criminal and judicial statistics, Ireland, 1891 [C.6782] (1892), p. 17; BPP, Judicial statistics, Ireland, 1901 [Cd. 1208, 1187] (1902), p. 11.

${ }^{56}$ Prison inspectors in 1824 noted most prisoners had committed minor offences: BPP, Fourth report of the inspectors general on the general state of the prisons of Ireland (173) (1826). Later prison reports emphasised 'drunkenness is the main source and cause of crime': BPP, Fifty-second report of the Inspectors-General on the general state of the prisons of Ireland, 1873 [C.966] (1874), p. 13; BPP, Fiftythird report of the inspectors-general on the general state of the prisons of Ireland, 1874; with appendix [C.1256] (1875), p. 13.

${ }^{57}$ S. Kilcommins, I. O'Donnell, E. O’Sullivan and B. Vaughan, Crime, Punishment and the Search for Order in Ireland, p. 13. For example, in the 1860s, the number of police in Ireland were approximately half the number of those in England and Wales (13,812 versus 22,622) but the population of Ireland was only a quarter: BPP, Judicial statistics, 1864, Ireland [3563] (1865).

${ }^{58}$ For example, in the 1880 s, the Dublin Metropolitan Police had more police per capita (336 per 100,000 capita) than the London Metropolitan Police (230 per 100,000 capita), and much higher police per capita compared with similarly-sized cities, such as Manchester and Leeds (230 and 120 per 100,000 capita): BPP, Return of Cost of Police in Boroughs of Great Britain of over 100,000 Inhabitants, and Police District of Dublin (326) (1888).

${ }^{59}$ Tipperary, the county in which Clonmel Gaol was situated, had a large police presence relatively to the population (442 per 100,000 capita according to the 1891 census).
} 
Apprehension rates were high (75 per cent), consistently higher than contemporary apprehension rates in England and Wales (50 per cent). ${ }^{60}$ The higher police presence led contemporaries to argue the Irish police force had better knowledge of the character of those apprehended for crimes committed. The majority of those apprehended were previously known to police and, of those known, the majority were of previous good character, primarily because many had committed only minor offences.$^{61}$ If we assume law enforcement officers were equally efficient throughout Ireland, this implies the likelihood of being detected, and penalised, for committing a crime was uniformly distributed through the island.

Tracing levels of criminality over time is made difficult by the fact that what was deemed a criminal offence changed. For example, a person who selects into a criminal activity in 1841 may repeat the same activity in 1891, but no longer be deemed to be a criminal for doing so. Also, the social tolerance for types of behaviour can change, and some minor offences can be punished with greater or less vigour depending on prevailing social norms. Perhaps the case in point was drunkenness, which was prosecuted with greater intensity following the 1872 Licencing Act. ${ }^{62}$

Criminal justice statistics, published annually from 1864, were intended to be used to make comparisons between Ireland and England, but their function evolved to provide comparison of prevailing crime trends. These data show that over the period 1864 to 1910, summary offences vastly outnumbered indictable offences by a ratio of 28 -to-1. Figure 2 shows trends in indictable offences for this period. ${ }^{63}$ There is significant variation in the data, with clear peaks $(1864,1881,1882,1898,1908)$ and troughs $(1888-1894) .{ }^{64}$ Figure 3 shows the distribution of indictable offences, the overwhelming majority of which were classified as 'offences against property without violence'.

While non-violent larceny was the main crime in this period, during the spike in crime in 1881 and 1882 the majority of these were for offences such as writing threatening letters, the most common form of 'agrarian outrage' during the Land War. ${ }^{65}$ Summary offences, shown in Figure 4, do not display such extreme variability. ${ }^{66}$ Of the 206,193 summary offences proceeded against in 1881, 78,573 were for 'drunkenness and drunk and disorderly'. The second-most common offence was common assault, with 30,088 cases proceeded against, and it was observed both were 'closely connected with one another' ${ }^{67}$ Data from parliamentary returns of the number of people arrested for drunkenness show it was a common offence throughout the island. ${ }^{68}$

Contemporaries were aware summary offences dominated the criminal justice system, and argued other indicators of crime were more appropriate to gauge the level of criminal activity. Their view was summary offences were primarily of a 'civil nature', and so should be excluded from the statistics. ${ }^{69}$ Another approach was to assess "fresh crime" in a year: "the statistics of commitments of persons not previously committed to any

\footnotetext{
${ }^{60}$ BPP, Criminal and judicial statistics, 1873, Ireland [C.1034] (1874), p. 28

${ }^{61}$ The English police forces had less knowledge of the character of those proceeded (34\% of cases proceeded against were of characters unknown versus $16 \%$ in Ireland), a factor which was attributed to 'the greater number of foreigners and the greater aggregation of the people in cities and towns in England than in Ireland': BPP, Criminal and judicial statistics, 1872, Ireland [C.851] (1873), p. 31.

${ }_{62}$ BPP, Criminal and judicial statistics, 1871, Ireland [C.674] (1872), pp. 31-32; BPP, Criminal and judicial statistics, 1873, Ireland [C.1034] (1874), p. 16.

${ }^{63}$ The number of offences averaged 8,146 per year and 168 per 100,000 capita.

${ }^{64}$ The coefficient of variation for both the number of offences and offences per capita is $21 \%$ and $24 \%$.

${ }^{65}$ E. McLaughlin, 'Competing forms of cooperation? Land League, Land War and cooperation in Ireland, 1879-1921', Agricultural History Review, 63:1 (2015), 81-112.

${ }^{66}$ The number of summary offences averaged 220,092 and the number of offences per capita averaged 4,490 per 100,000. The coefficient of variation for the number of summary offences and the number of summary offences per 100,000 capita are $11 \%$ and $8 \%$.

${ }^{67}$ Drunkenness and common assault together accounted for 53\% of all summary offences: BPP (1892), p. 17.

${ }^{68}$ In the 1877 and 1883 the mean arrests per 100,000 capita was 1,902 and 1,745, with standard deviation of 694 and 623 . Arrests per 100,000 capita in 1883 there were 3,604 in Dublin versus 2,162 in Tipperary: BPP (1877); BPP (1883).

${ }^{69}$ The "number of "indictable offences" may be taken as the more correct standard by which to measure the prevalence of crime in relation to the population': BPP, Judicial statistics, Ireland, 1901 [cd 1208, 1187] (1901), p. 10.
} 
prison afford the best goal test of the amount of fresh crime in the year' ${ }^{70}$ An approach used by criminologists to measure crime more consistently across time is to use homicides. ${ }^{71}$ Homicide has the attraction of having a consistent definition (i.e., a body count), is less subject to under-reporting, and is correlated with other forms of crime. ${ }^{72}$ Homicide rates in nineteenth-century Ireland were low by modern standards. ${ }^{73}$

The final issue to understand is how crime was tried and punished. Both indictable and summary offences were punished with a mixture of custodial and non-custodial sentences. Custodial sentences were the predominant punishment for indictable offences; fines had a similar function for summary offences. Legislation stipulated specific fines for breaches for many summary offences. ${ }^{74}$ There was a much greater reliance on fines in Ireland than in England for comparable offences. ${ }^{75}$ This, contemporaries suggested, was because Petty Sessions, the court which heard such cases, had a financial interest in the fines imposed. ${ }^{76}$

The most severe punishment, execution, was rare, with only 0.01 per cent of indictable offences receiving the death penalty in 1881 . Shorter sentences (under six months) were more widely allocated as a punishment for indictable offences. However, most of the prison population consisted of summary offenders. With respect to these more minor offences, fines were the most common punishment, even in the case of drunkenness and common assault. However, ten per cent of drunkenness and common assault offences received custodial sentences. ${ }^{77}$ The custodial sentences given for drunkenness in particular put enormous strain on the prison system and accounted for 50 per cent of all prisoners in Ireland in 1900. ${ }^{78}$

The average daily imprisonment rate from 1839 to 1909 is shown in Figure 5. The average daily rate was 62 per 100,000 capita, with a noticeable peak during the Famine. The reports from the inspectors general of prisons outline three reasons why the prison population increased: distress from the Famine, the sudden cessation of transportation to Australia as a form of punishment, and the Vagrancy Act, which criminalised vagrancy and prescribed a custodial sentence. ${ }^{79}$ The effect of the Famine was said to have 'quadrupled the evils occasioned by the two last' ${ }^{80}$ All these factors led to overcrowding of the prison system, with 12,883 prisoners held in prisons designed to hold 5,655. The Famine period withstanding, the data indicate custodial sentences were quite common. ${ }^{81}$

\footnotetext{
${ }^{70}$ First-time offenders were $68 \%$ of total offenders imprisoned in $1873,77 \%$ in 1881 and $44 \%$ in 1891 . However, the data do not provide details of those deemed to have committed "fresh crime" who received non-custodial sentences: BPP (1873), p. 45.

${ }^{71}$ See, e.g., I. O'Donnell, 'Lethal violence in Ireland, 1841 to 2003', British Journal of Criminology, 45 (2005), 671-695; R. McMahon, Homicide in Pre-Famine and Famine Ireland (Liverpool, 2013).

${ }^{72}$ P. Fajnzylber, D. Lederman and N. Loayza, 'What causes violent crime?', European Economic Review, 46:7 (2002), $1323-1357$.

${ }^{73} \mathrm{O}$ 'Donnell compares homicide statistics in Ireland at the end of the 1800s and the 1900s and finds the homicide rate had declined from 1.9 to 1.2 per 100,000: I. O'Donnell, 'Killing in Ireland at the turn of the centuries: Contexts, consequences and civilising processes', Irish Economic and Social History, 37 (2010), 53-74. This is quite low compared with modern standards; a 2011 UN report gives a global average of 6.9 per 100,000, with figures between 3 and 4 per 100,000 in Asia, Europe and Oceania: United Nations Office on Drugs and Crime, Global Study on Homicide 2011: Trends, Contexts, and Data (Vienna, 2011).

${ }^{74}$ BPP, Criminal and judicial statistics, 1871, Ireland [c. 674] (1872), p. 39.

${ }^{75}$ In England the ratio of fines to imprisonment was 1-to-3.5; in Ireland this was 1-to-8: BPP, Criminal and judicial statistics, 1881 , Ireland [C.3355] (1882), p. 30.

${ }^{76}$ BPP, Criminal and judicial statistics, 1881, Ireland [C.3355] (1882), p. 18. Fines also introduce an element of selection: if an individual can afford to pay a fine, they avoid custodial sentences and are therefore not measured. Meanwhile, those unable to afford fines received custodial sentences. However, socio-economic variables included in prison registers can control for some facets of this selection.

${ }^{77}$ We are likely, therefore, to be observing poorer individuals, who could not afford these fines.

${ }_{78}$ BPP, Twenty-second report of the General Prisons Board, Ireland, 1899-1900; with an appendix [cd. 293] (1900), p. 9.

${ }^{79} \mathrm{BPP}$, Twenty-sixth report of the inspectors-general on the general state of the prisons of Ireland, 1847 [952] (1847-48).

${ }^{80}$ Another factor was people that were receiving indoor poor relief were rioting in an attempt to get transferred from the workhouse to the prison system, where conditions were considered better: BPP, Twenty-sixth report of the inspectors-general on the general state of the prisons of Ireland, 1847 [952] (1847-48), p. 8.

${ }^{81}$ For the purpose of anthropometric analyses of the Famine, such as Blum et al., 'Scarring and selection in the Great Irish Famine', it is important those incarcerated during the Famine are excluded from the analysis. This is because this period saw individuals selected into prison in ways which are difficult to quantify.
} 
The spike in the prison population during the Famine illustrates an important point about crime and institutions: changes in institutional structures affected the prison population at the same time as a severe economic shock. However, without knowledge of this changing institutional context it might be appealing to attribute all of the increase in incarceration solely to the changing economic circumstances. Any analysis of prison populations needs to be aware of these changing institutional contexts. Prisons may cater to different segments of criminal classification depending on the time period. If possible, various measures need to be considered which re-weight prison samples to mitigate the impact of these institutional changes. ${ }^{82}$

What is evident from the historical record is there were effectively three "prison regimes" over the nineteenth century. The first, from 1791 to 1853 , saw the removal of a segment of criminals from the UK as a punishment for what were deemed the most severe crimes: over this period, 26,500 convicts were transported to Australia. ${ }^{83}$ Transportation was replaced with penal servitude and this was accompanied by the opening of the first "state prison", Mountjoy, in 1850.

A further administrative change occurred in 1877, when prisons throughout Ireland were centralised under the General Prisons Board. This resulted in a change in the classification of prisoners being held county gaols such as Kilmainham and Clonmel: they were to be used for 'untried and prisoners under sentence, males for sentences not exceeding 12 months and females not exceeding 6 months' ${ }^{84}$ From 1877 onwards, prisoners serving longer-term sentences were sent to specialist convict prisons: Lusk (Dublin), Mountjoy (Dublin), and Spike Island (Cork).

\section{Economic Biases in Prison Data}

Given our knowledge of the institutional and historical context, how did individuals select into crime across the post-Famine era between the 1860s and 1910s? How responsive was crime to year-on-year fluctuations in economic and social conditions, such as to the business cycle? Bodenhorn et al. describe a mechanism which suggests economic opportunity may alter the composition of prison samples. ${ }^{85}$ Contemporaries were also interested in this question. For example, the criminal justice statistics compilers in 1873 remarked how 'notwithstanding the unfavourable character of the harvest last year, producing pressure on the poor and withdrawal of saving' there was a decrease in year-on-year crime; 'the pressure has been attended with a diminution of crime' ${ }^{86}$

Changing opportunity costs of crime, such as job opportunities and levels of income, may alter the necessity and attractiveness of criminal activity. If such a bias is detected, prison samples may be subject to bias and this bias may change as the opportunity cost of crime changes. Some of these biases may be detected by comparing, and then correcting, prison samples using census reports. ${ }^{87}$ However, such a methodology cannot disentangle economic from institutional selection mechanisms, and hence we need to make use of some simple

\footnotetext{
${ }^{82}$ For example, prisoners could be assigned a weight according to their relative representativeness in the closest census year, by religion and by profession; see M. Blum, C. L. Colvin, L. McAtackney, and E. McLaughlin, 'Women of an uncertain age: Quantifying human capital accumulation in rural Ireland in the nineteenth century', Economic History Review, 70:1 (2017), 187-223.

${ }^{83}$ Kilcommins et al., Crime, Punishment and the Search for Order in Ireland, p. 17. The cumulative figure for transportation is eyecatching, but it was less dramatic on an annual basis; over the period 1839-44 transportation accounted for $9 \%$ of all sentences.

${ }^{84}$ BPP, First report of the General Prisons Board, Ireland, 1879; with appendices [C.2447] (1878-79), p. 37.

${ }^{85}$ Bodenhorn et al., 'Sample-selection biases and the "industrialization puzzle"".

${ }^{86} \mathrm{BPP}$, Criminal and judicial statistics, 1872, Ireland [C.851] (1873), p. 16. During the Land War period, comparisons were made between the crime statistics and falls in bank deposits and use of the poor law as indicators of 'pressure': BPP, Criminal and judicial statistics, 1881, Ireland [C.3355] (1882), p. 15

${ }^{87}$ While individual-level census data no longer survive for Ireland, Parliamentary Papers report summary statistics by census district: Blum, Colvin and McLaughlin, 'Scarring and selection in the Great Irish Famine'.
} 
econometrics. We therefore test whether the prison population was responsive to changing economic conditions using time series analysis of key macroeconomic performance indicators.

Adopting the measures most common to the criminology literature, we use the annual homicide rate per 100,000 inhabitants and the average daily incarceration rate per 100,000 inhabitants to proxy crime and conviction on the island. The following indicators serve as a proxy of economic opportunity, i.e., the opportunity cost of criminal activity: real GDP per capita ( $£, 1841$ prices); bank deposits per capita ( $£$, real terms); a price index of the Dublin stock market $(1964=100)$; and an index of agricultural prices $(1856-60=100)$. Indices depicted in Figure 6 illustrate the data we used in our analysis for the sub-period 1860 to 1910. The data we use for our econometric analysis refer to the full period 1854 to 1913 so as to exclude the core Famine years, which we already know to have been very different; analysis which would include those incarcerated during this demographic catastrophe would not uncover any of the more nuanced selection biases we are aiming to discover.

As the data are time-series in nature, we test for stationarity; we cannot reject the presence of unit roots and subsequent analysis of the data accounts for this. Basic levels OLS regressions indicate all variables are cointegrated. We therefore report autoregressive distributive lag models (ARDL (p,q)) with an error correction component. ${ }^{88}$ In these regressions, the $\beta$ represents long-run correlation and $\alpha$ is the error correction. Full results are reported in Tables 1 and 2.

For incarceration rates all regressions display negative and statistically significant values for $\alpha$, whereas values for $\beta$ are positive but not statistically significant. For homicide, the autoregressive lag models all regressions display negative and statistically significant values for $\alpha$, whereas values for $\beta$ are negative for GDP and the stock exchange indices, but positive for deposits and the price index. However, only deposits are statistically significant. The implication of this exercise is there is some weak evidence that as Ireland got richer there was a fall in crime (as measured here by incarceration rates and homicide).

But our results do not provide very strong evidence the economic performance of the Ireland influenced homicide or incarceration rates in any meaningful sense. We therefore cannot conclude the size and composition of the prison population in Ireland was particularly responsive to changing economic conditions. ${ }^{89}$ The alternative hypothesis, that institutions mattered more than economics, is a closer approximation to the historical record of crime trends in Ireland; in fact, we see some evidence of structural breaks in the 1870s coinciding with changes in prison regimes.

This result runs counter to the view held by most contributors to the literature on the economics of crime..$^{90}$ But it is far less surprising following a broader reading of the criminology literature. Pratt and Cullen's metastudy of the determinants of violent crime outlines at least seven competing macro theories commonly tested in this literature. ${ }^{91}$ They find rational choice theory, classically associated with Becker, ${ }^{92}$ receives the weakest support across studies. Social disorganisation theory, which stresses the role of institutions, receives the strongest empirical backing.

\footnotetext{
${ }^{88}$ In this setup, p refers to lags of the crime indicator and q to lags of the economic indicator, with lags chosen by the Akaike information criterion. We also test for structural breaks and where breaks are detected the model is subsequently adjusted. Breaks were detected for incarceration rates and the price index, and for homicides and real deposits.

${ }^{89}$ Historians of crime may not find this result particularly surprising, but economists may speculate on an economic explanation: criminal justice is costly; when state revenues fall, one way of reducing costs is to reduce policing or incarcerate fewer individuals, offsetting any increase in crime. We find no evidence of such a reduction, however.

${ }^{90}$ See, e.g., Freeman, 'The economics of crime'.

${ }^{91}$ Pratt and Cullen, 'Assessing macro-level predictors and theories of crime'

${ }^{92}$ Becker, 'Crime and punishment'.
} 


\section{Conclusion}

We argue any differences in selection into crime across time were more likely the result of institutions than economics. More specifically, we take the view that the various institutional reforms to the criminal justice system are key to understanding any changes to selection into crime. We collapse these institutions into three so-called "prison regimes", and mark these with vertical lines in Figure 5. Anthropometric studies using Irish prison registers must control for these prison regimes, alongside other political events which potentially saw a change in the attributes of prisoners. Scholars working with prison data pertaining to other times and places must make similar adjustments.

Prison registers can be used to answer questions about developments in Irish living standards. We can also use them to re-visit issues such as what was the long-term effect of the Industrial Revolution and Famine. A study by Blum looks at the effect of famine during the first World War on the German population using military records. ${ }^{93}$ The Blum methodology can be used to analyse the effects of ecological distress in Ireland, including the Great Irish Famine of the 1840s, and agricultural crises in the early 1860s and late 1870s. We do exactly this in a companion paper. ${ }^{94}$

An additional question to be addressed is the effect of slum conditions on urban populations. Dublin city grew steadily from a population level of 176,610 in 1813 to 290,638 in $1901,{ }^{95}$ however the city was reputed as being a slum. ${ }^{96}$ These slum conditions differed from those reported in contemporary British, European and North American cities as the Dublin slums were not a corollary of Irish industrialisation. Therefore, it would be interesting to see how conditions in the Dublin city differed from those elsewhere, in particular in comparison to Belfast. Such an exercise would likely require the use of spatial data and methods from the digital humanities. For example, McCrea uses our Kilmainen Gaol prison register data on ward or street of residence of Dublin's prisoners to locate areas of poverty and deprivation..$^{97}$

\section{Acknowledgements}

This research note started life as a series of appendices to 'Scarring and selection in the Great Irish Famine', QUCEH Working Paper Series, Queen's University Belfast, Paper No. 17-08 (September 2017). We thank all those who commented on that paper, especially Cormac Ó Gráda. We thank Philip Fliers for advice on time series econometric methods, and the editor (Graham Brownlow) and two anonymous referees for helping us revise the current paper.

\section{Declaration of Conflicting Interests}

The authors declared no potential conflicts of interest with respect to the research, authorship and/or publication of this article.

\footnotetext{
${ }^{93}$ M. Blum, 'Government decisions before and during the First World War and the living standards in Germany during a drastic natural experiment', Explorations in Economic History, 48:4 (2011), 556-567.

94 Blum et al., 'Scarring and selection in the Great Irish Famine'.

${ }^{95}$ W. E. Vaughan and A. J. Fitzpatrick, Irish Historical Statistics: Population 1821-1971 (Dublin, 1978).

${ }^{96}$ J. Prunty, Dublin Slums, 1800-1925: A Study in Urban Geography (Dublin, 1998).

${ }^{97}$ A. McCrea, "Dear, dirty Dublin": A framework for the integration of historic institutional records to GIS and its application to the prisoners of Kilmainham Gaol, Dublin', MSc Dissertation in Geographical Information Systems and Science, Kingston University, London (2016).
} 


\section{Funding}

Colvin acknowledges financial support from the Netherlands Institute for Advanced Study in the Humanities and Social Sciences. The authors received no other financial support for the research, authorship, and/or publication of this article.

\section{Author Biographies}

Eoin McLaughlin is Senior Lecturer in Economics at University College Cork, where he is also a research affiliate of the university's Environmental Research Institute. Additionally, he is a research affiliate of the Centre for Economic History at Queen's University Belfast. Besides his ongoing co-authored projects on Irish prison data, he has research interests in business history, financial history, social history, economic geography, and environmental economics.

Christopher L. Colvin is Senior Lecturer in Economics at Queen's University Belfast, where he is also a research associate of the university's Centre for Economic History. Besides his ongoing co-authored projects on Irish prison data, he has research interests in business history, financial history, cultural economics, innovation policy, and economic history pedagogy.

Matthias Blum is Data Scientist at the German Medical Association, Berlin, and a research affiliate of the Centre for Economic History at Queen's University Belfast. Besides his ongoing co-authored projects on Irish prison data, he has research interests in anthropometric history, health economics, development economics, and economic history pedagogy. 
Table 1: Autoregressive distributed lag models of incarceration rates and economic indicators (with error correction)

\begin{tabular}{lcccc}
\hline & $(1)$ & $(2)$ & $(4)$ & $(3)$ \\
\hline Economic indicator & Real GDP pc & Real deposits pc & Price index & Stock exchange \\
Model & ARDL(4,4) & ARDL(4,2) & ARDL $(4,0,0)$ & ARDL $(1,2)$ \\
Sample & $1854-1909$ & $1854-1909$ & $1854-1909$ & $1869-1909$ \\
\hline$\alpha$ & $-0.290 * * *$ & $-0.282 * * *$ & $-0.298 * * *$ & $-0.293 * * *$ \\
& $(0.051)$ & $(0.049)$ & $(0.053)$ & $(0.100)$ \\
$\beta$ & 0.160 & 0.060 & 0.039 & 0.053 \\
& $(0.104)$ & $(0.044)$ & $(0.384)$ & $(0.095)$ \\
\hline Observations & 56 & 56 & 56 & 41 \\
R-squared & 0.744 & 0.725 & 0.704 & 0.302 \\
Adj R-squared & 0.694 & 0.685 & 0.668 & 0.225 \\
Log likelihood & -175.386 & -181.172 & -183.208 & -130.769 \\
F & 16.090 & 16.485 & 10.563 & 4.857 \\
\hline Structural break & n.a. & n.a. & 1873 & n.a. \\
Parameter stability & 0.600 & 0.717 & 0.712 & 0.629 \\
I(0) & $* * *$ & $* * *$ & $* * *$ & $*$ \\
I(1) & $* * *$ & $* * *$ & $* * *$ & n.s. \\
\hline
\end{tabular}

Sources: Authors' calculations, using parliamentary papers cited in text; L. Kennedy and P. Solar, P., Irish Agriculture: A Price History (Dublin, 2007), for agricultural prices; R. S. Grossman, R. C. Lyons, K. H. O'Rourke and M. A. Ursu, 'A monthly stock exchange index for Ireland, 1864-1930', European Review of Economic History, 18:3 (2014), 248-276, for stock market data; and F. N. G. Andersson and J. Lennard, 'Irish GDP between the Famine and the First World War: Estimates based on a dynamic factor model', European Review of Economic History, 23:1 (2019), 50-71, for GDP estimates. 
Table 2: Autoregressive distributed lag models of homicide rates and economic indicators (with error correction)

\begin{tabular}{lcccc}
\hline & $(1)$ & $(2)$ & $(3)$ & $(4)$ \\
\hline Economic indicator & Real GDP pc & Real deposits pc & Price index & Stock exchange \\
Model & ARDL(2,3) & ARDL(2,0) & ARDL(2,0) & ARDL $(2,1)$ \\
Sample & $1854-1913$ & $1854-1913$ & $1854-1913$ & $1869-1913$ \\
\hline$\alpha$ & -0.580 & $-0.816 * * *$ & $-0.375 * * *$ & $-0.463 * * *$ \\
& $(0.147)$ & $(0.121)$ & $(0.122)$ & $(0.150)$ \\
$\beta$ & -0.137 & $0.089 * *$ & 0.657 & -0.199 \\
& $(0.107)$ & $(0.041)$ & $(0.586)$ & $(0.144)$ \\
\hline Observations & 60 & 60 & 60 & 45 \\
R-squared & 0.368 & 0.453 & 0.307 & 0.412 \\
Ad R-squared & 0.297 & 0.424 & 0.270 & 0.353 \\
Log likelihood & -246.729 & -242.403 & -249.483 & -186.973 \\
F & 7.751 & 15.459 & 5.305 & 4.878 \\
\hline Structural break & n.a. & $1899 *$ & n.a. & n.a. \\
Parameter stability & 0.787 & 0.772 & 0.639 & $0.994 * *$ \\
I(0) & $* * *$ & $* * *$ & $* *$ & $*$ \\
I $(1)$ & $* *$ & $* * *$ & $*$ & n.s. \\
\hline
\end{tabular}


Figure 1: Criminal justice system schema

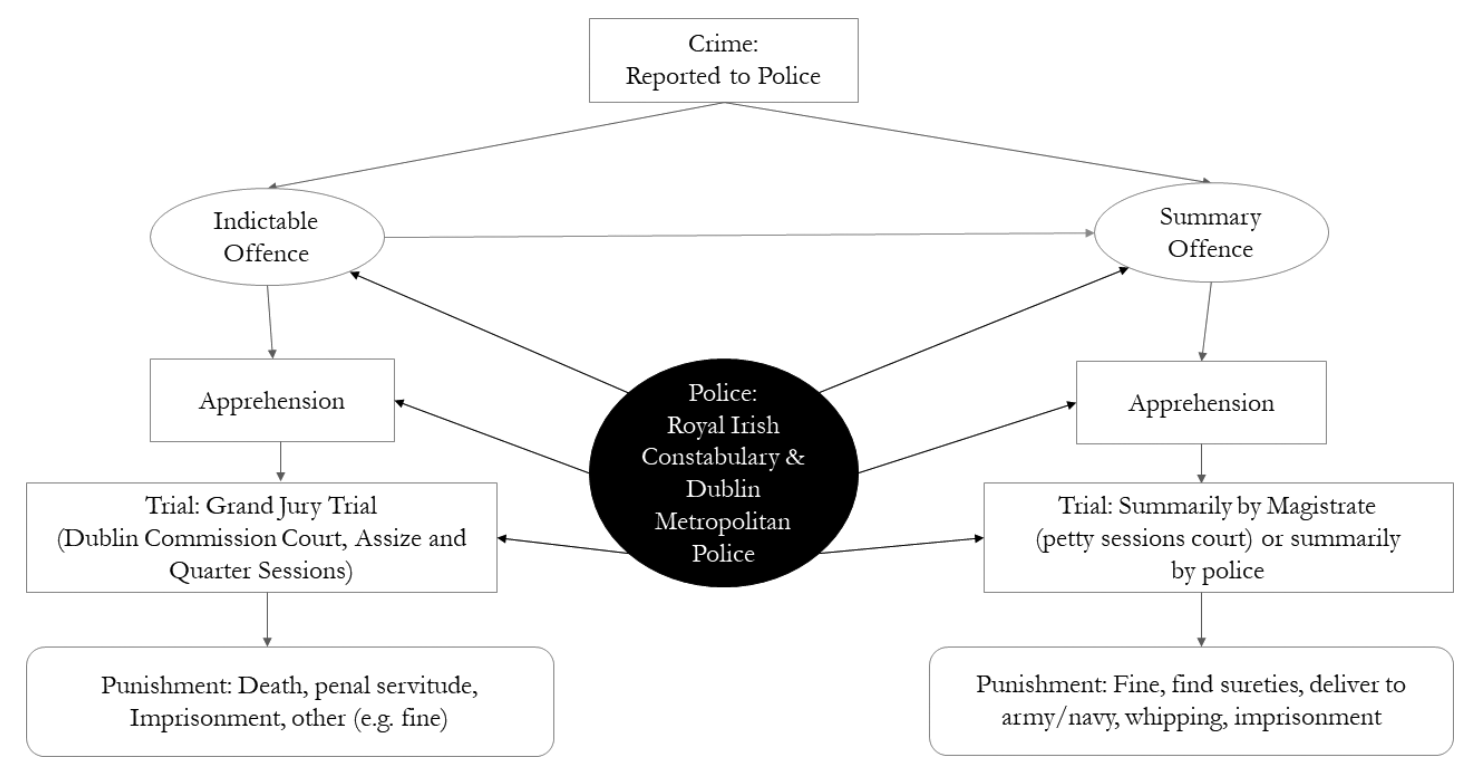

Sources: Authors' summary, using the annual Criminal and Judicial Statistics published as parliamentary papers cited in text. 
Figure 2: Indictable offences, 1864-1910

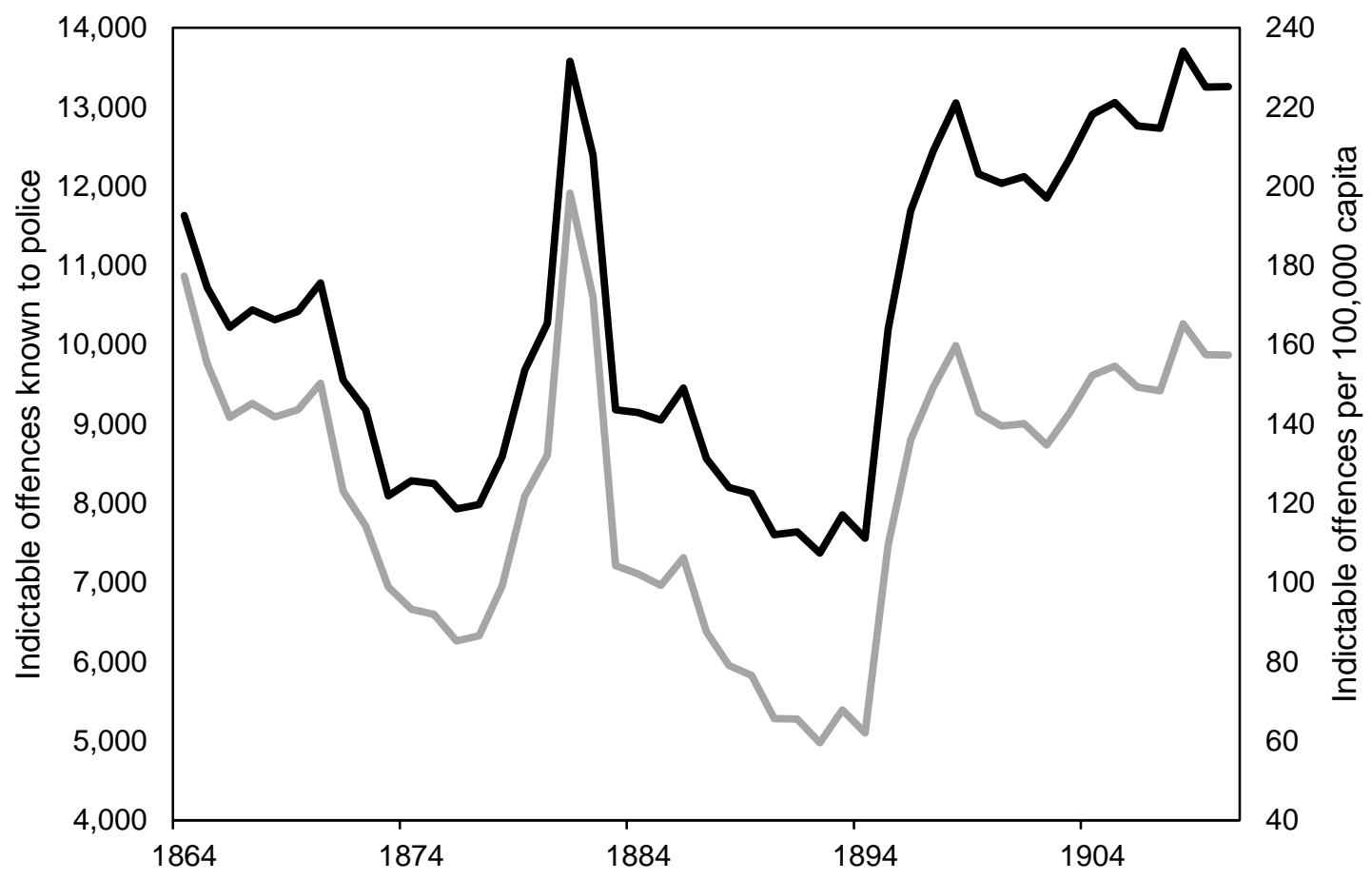

Number of indictable offences known to police _ Indictable offences per 100,000 capita

Sources: Authors' calculations, using the annual Criminal and Judicial Statistics published as parliamentary papers cited in text. 
Figure 3: Distribution of indictable offences committed, 1864-1910

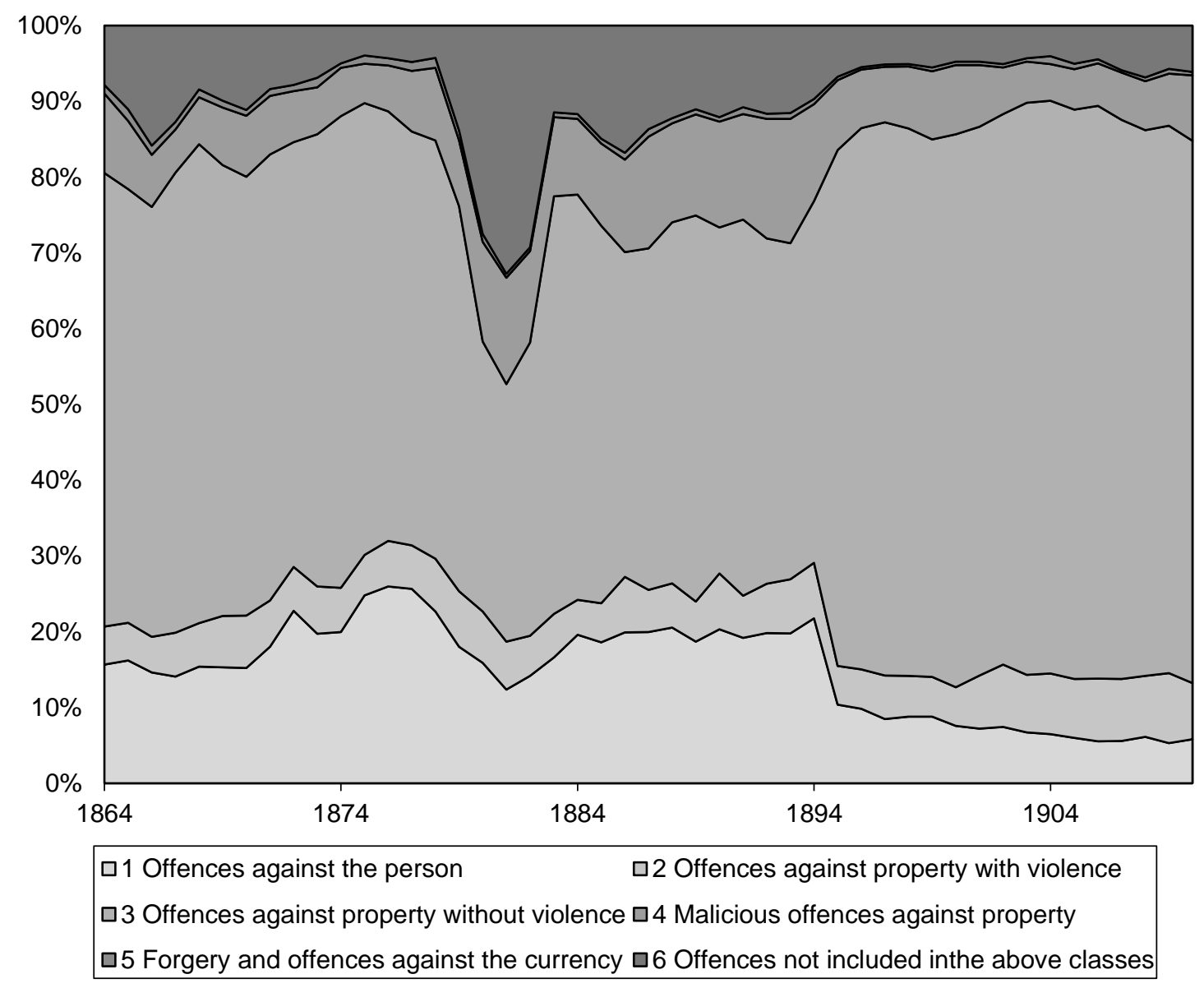

Notes: Indictable offences were comprised of 6 categories: (1) Offences against the person: Murder of infants aged one year and under; Other murders; Attempts to murder; Shooting at wounding, Stabbing \&c, to do bodily harm; Manslaughter; Attempts to procure miscarriage; Concealing the births of infants; Sodomy and bestiality; Attempts to commit and other unnatural misdemeanours; Rape; Assaults with intent to ravish and abuse; Defilement of girls under 13; Defilement of girls between 13 and 16 years of age; Abduction; Bigamy; Child stealing; Unlawful abandoning of Children under 2 years of age; Endangering the safety of passengers on railways; Assault and indicting bodily harm; Assaults, common; Assaults on Peace officers. (2) Offences against property with violence: Sacrilege; Burglary and housebreaking; Breaking into shops, warehouses \&c; Attempts to break into houses, shops, warehouses \& c; Robbery on the highway; Attempts to rob on the highway, and demanding money by menaces. (3) Offences against property without violence: Cattle Stealing; Horse Stealing; Sheep Stealing; Larceny to the value of $£ 5$ in dwelling houses; Larceny from the Person; Larceny by servants; Larceny, simple; Larceny on rivers, canals, wharfs \& c.; Stealing fixtures, shrubs growing, \& c.; Attempts to steal; Embezzlement; Larceny by servants in the post office; Receiving Stolen goods; Fraudulently obtaining goods by false pretences and attempts to defraud. (4) Malicious offences against property: Arson and other wilful burning; Felonies riot and demolishing buildings \&c.; Destroying goods in process of manufacture; Destroying trees, shrubs \& c. growing; Killing and maiming cattle; Malicious Injuries to property exceeding $£ 5$ in value; Other wilful and malicious injuries to property. (5) Forgery and offences against the currency: Forging and uttering forged instruments; Having in possession forged bank notes; Coining, and having implements for coining in possession; Uttering, printing off and having in possession counterfeit coin. (6) Offences not included in the above classes: Offences against the Queen as Authority and Person; Intimidation by threatening letters, notices, or otherwise; Having arms or ammunition without licence in a proclaimed district; Offences against game laws; Being at large under sentence of transportation or penal servitude; Perjury and subordination of perjury; Riot, breach of the peace etc; Keeping disorderly houses; Indecently exposing the person; Suicide, attempting to commit; Other felonies not included in the above; Other misdemeanours not included in the above.

Sources: See note under Figure 2. 


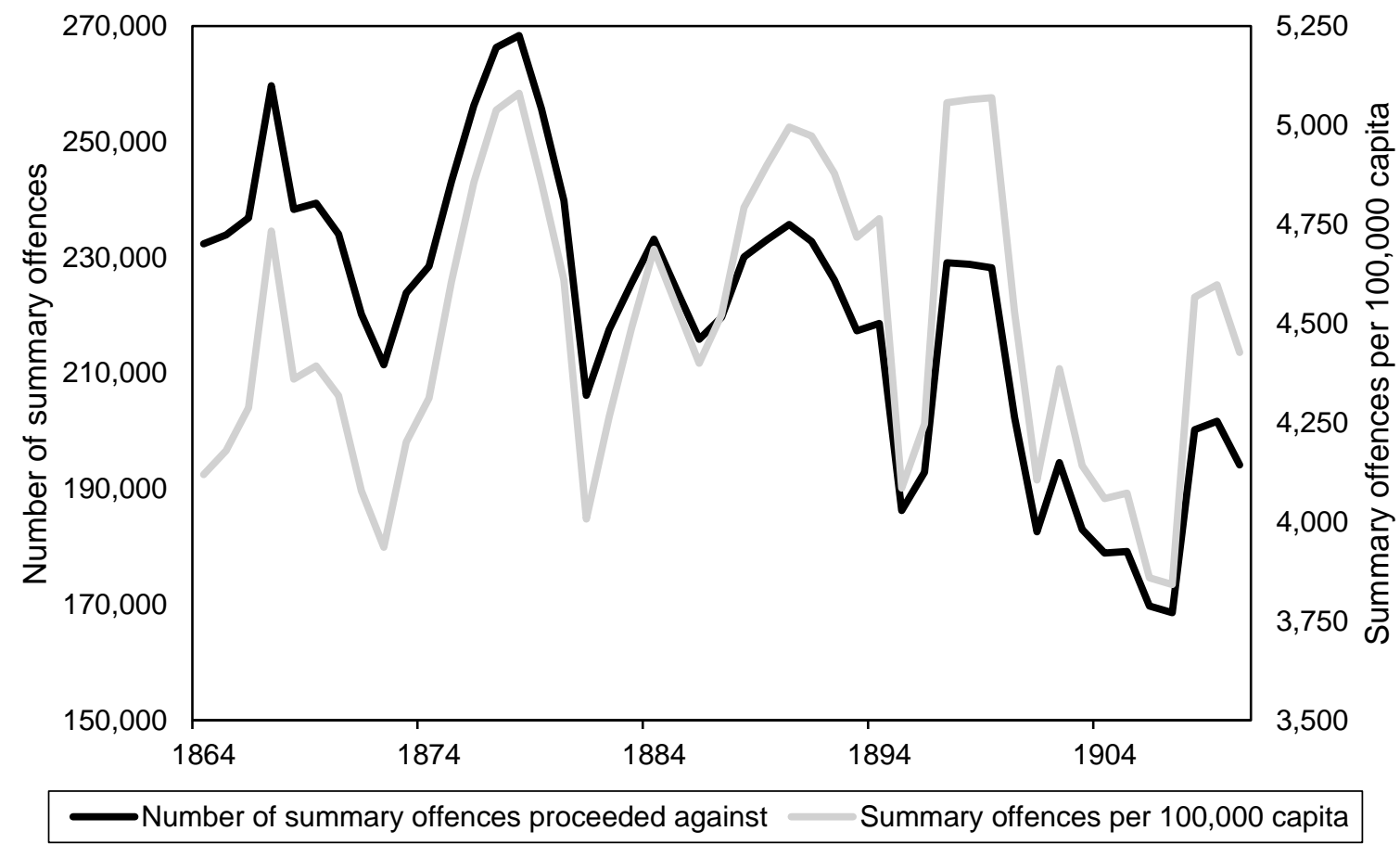

Notes: Summary offences related to petty crime: Adulteration of food, \& c, Act; Assaults, aggravated, on women and children; Assaults, on peace officers, resisting, obstructing \& c.; Assaults, common; Bastardy orders, disobeying; Breaches of the peace, want of sureties \& c.; Cattle plague orders, offences against; Chimney sweepers act, offences against; Cruelty to animals; Embezzlement; Employers and workmen act, 1875; Factory acts, offences against; Fisheries Acts, offences against; Game acts, offences against viz: Trespassing in the day time in pursuit of game, Night poaching and destroying game, Illegally selling or buying game, Poaching act, 1862, Other offences against game acts; Licencing acts, 1872-74 offences against, viz: Drunkenness and drunk and disorderly, Permitting drunkenness and disorderly conduct in licensed houses, Illegally selling intoxicating drinks, Adulteration of intoxicating liquors, Beerhouse Act offences against, Other offences under the licensing acts; Lord's Day Act, offences against; Local acts and borough bye-laws, offences against; Maliciously destroying fences, walls, gates, \& c.; Maliciously destroying fruit and vegetable productions; Maliciously destroying trees, shrubs \&c.; Other malicious and wilful damage and trespass; Mutiny acts, offences against: Army Act, Navy Act, Militia Act, Mercantile marine acts, offences against; Nuisance and offences against health, viz: Public health acts; Smoke acts; Sewers act; Nuisance, removal act.; Common lodging houses acts; Selling and exposing for sale unsound food; Other sanitary offences; Pawnbrokers act, offences against, viz: By pawnbrokers, By persons unlawfully pledging or disposing, Other offences; Police acts, offences against: Unlawfully possessing goods, Offences punishable as misdemeanours, Constables neglecting their duty, Other offences, not falling under special heads, Prevention of crime act, 1871, sec 7 (special offences by persons twice committed); Poor law acts, offences against: Deserting or neglecting to support family, Disorderly conduct in the workhouse, Damaging workhouse clothing, bedding etc; Refreshment houses and wine licences act; Revenue laws, offences against: Customs acts; Excise acts (including Hawkers and peddlers act); Salmon fisheries act, offences against; Stealing or attempts to steal, viz. -: Larceny, by offenders under 16 years (Juvenile offenders act), Larceny, under value of $5 \mathrm{~s}$ and on pleading guilty (Criminal Justice Act), Larceny, above value of $5 \mathrm{~s}$, on pleading Guilty (criminal justice act), Larceny, or larceny from person, attempting to commit (Criminal Justice Act), Dogs, birds, or beasts (\&c), Fruit or vegetable productions, Fences, wood \& c., Trees, Shrub, etc.; Vagrancy acts, offences against: Prostitutes, Begging, Having no visible means of subsistence \& c., Having implements for homebreaking, etc., Found in enclosed premises for unlawful purposes, Frequenting places of public resort, \&c, to commit felony, Incorrigible rogues, Other offences against Vagrant Act; Vaccination Acts, offences against; Ways acts, offences against: Stage and Hackney Carriage Acts, Highway Act (including road nuisances), Watermen's Act, Railway Acts; Weights and Measures Act, offences against; Other offences (not included under the above heads).

Sources: See note under Figure 2. 
Figure 5: Prison regimes, incarceration rate and homicide rate, 1840-1910

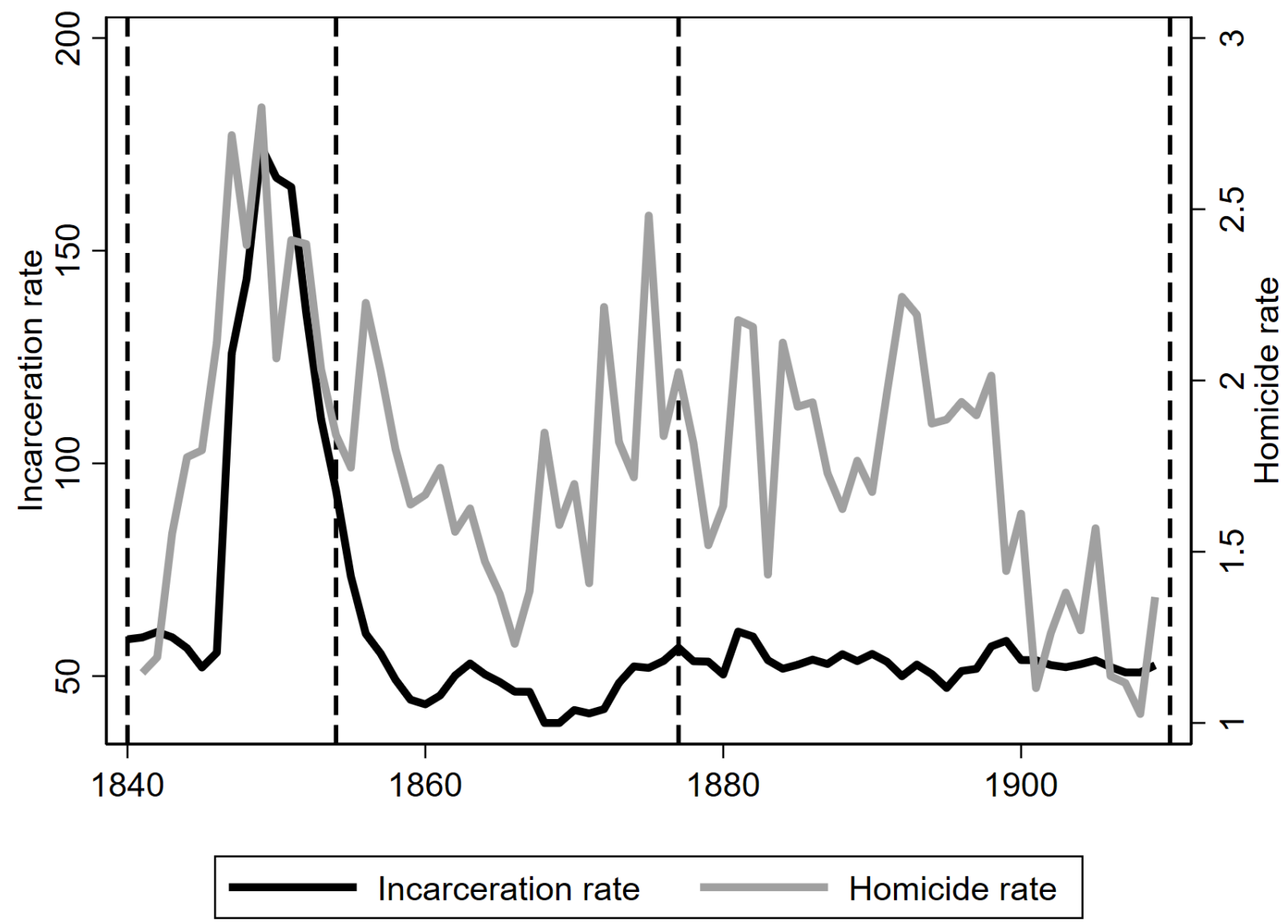

Notes: Vertical lines represent the beginning and end of the three prison regimes we have identified in our analysis (1839-1853, 1854-1876 and 1877-1910). Incarceration rate and homicide rate are expressed per 100,000 capita.

Sources: See note under Figure 2. 
Figure 6: Crime and macroeconomic indicators, 1860-1910

(a) Incarceration rate

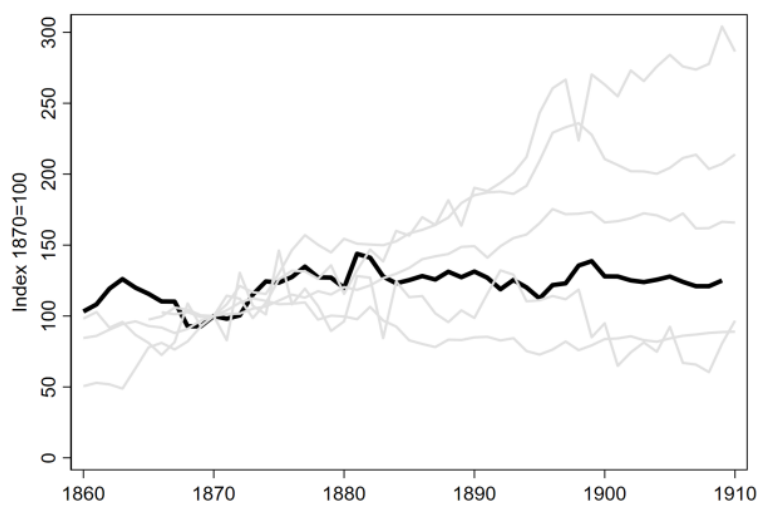

(c) Real GDP per capita

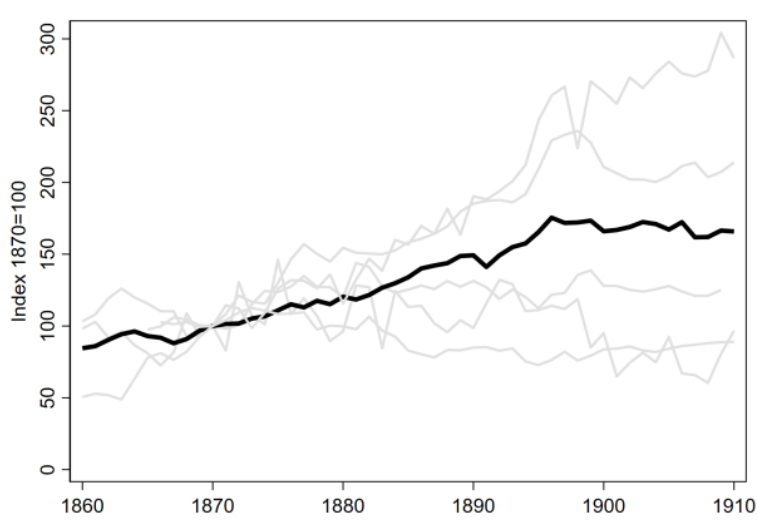

(e) Dublin stock market

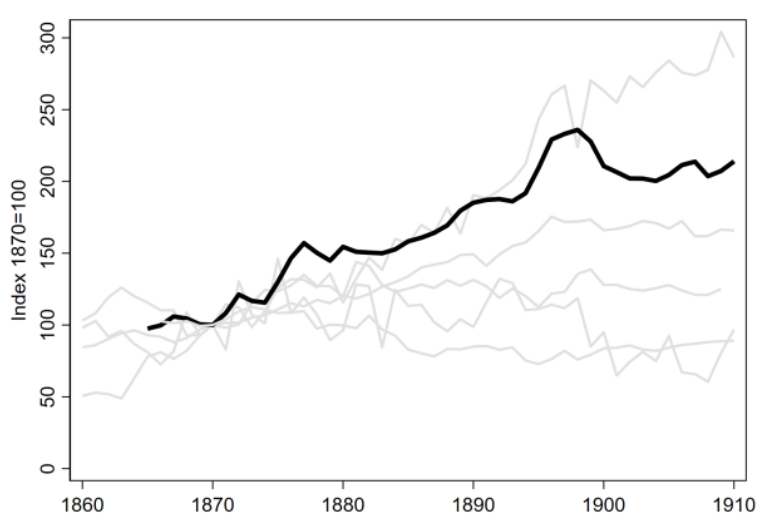

(b) Homicide rate

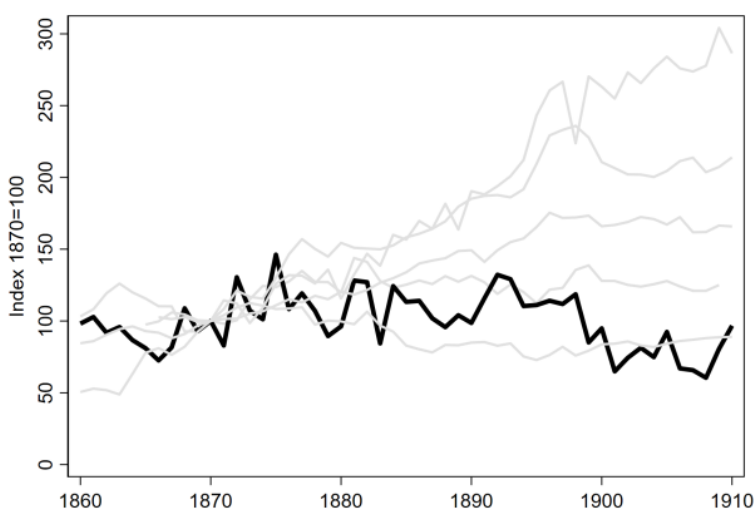

(d) Deposits per capita

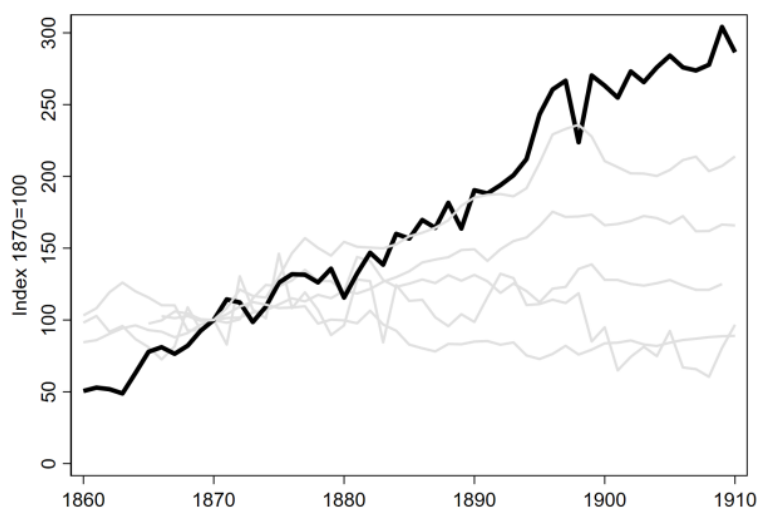

(f) Agricultural prices

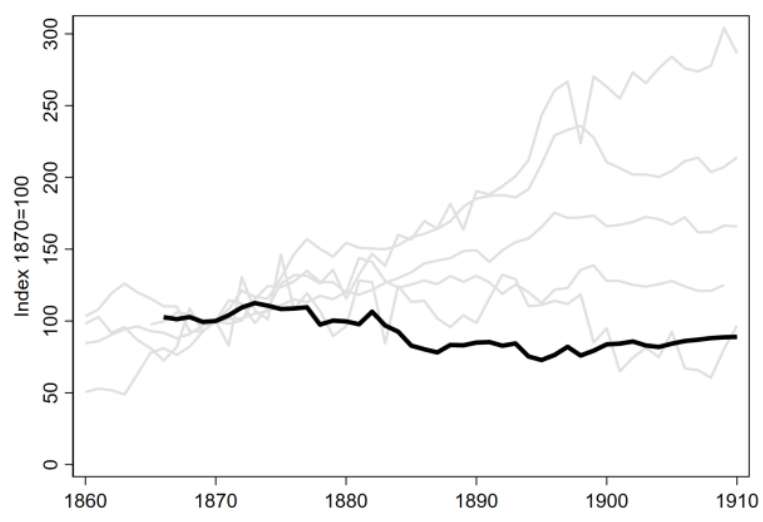

Sources: See notes under Table 1 and Figure 2. 